\title{
De onde vem e para onde vai a encenação?
}

\section{Patrice Pavis}
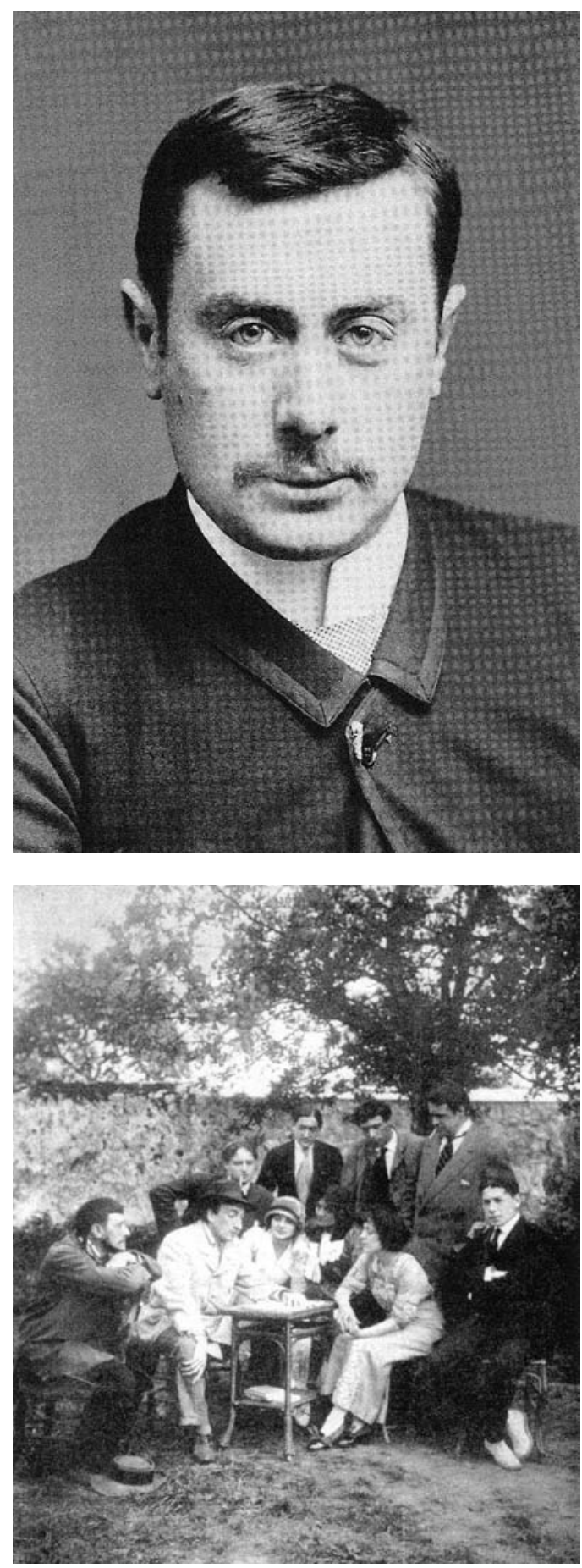

\section{Vasta questão!}

Seria o mesmo que perguntar donde vem a humanidade e para onde vai... Limitemo-nos a observar de onde provêm o termo e a noção de "encenação" e para que podem servir ainda hoje. Por agora, partamos da acepção mais vasta possivel, isto é, a maneira como o teatro se revela numa representação concreta, para um dado público. Convém, antes de mais, distinguir o "teatro" em geral, a representação ou realização cénica de uma obra num dado momento, o "espectáculo", ou seja, essa representação no seu aspecto visual e factual, e a "encenação", como normativização do teatro para uma representação com fins cénicos.

Se quisermos conhecer a actual situação do teatro, precisamos de observar o modo como a encenação o concretiza. Convém também lembrarmo-nos das origens da encenação, pois se sempre existiu a organização prática do espectáculo, a invenção do encenador situa-se por volta dos anos 80 do século XIX e a da encenação remonta aos princípios do mesmo século: "É somente cerca de 1820 que se começa a falar de encenação no sentido que hoje Ihe atribuimos. Antes, encenação significava adaptar um texto literário com vista à sua representação teatral. Encenar um romance significava adaptá-lo à cena" (Dort 1971: 51).

Cerca de 1880, a encenação já passa mais por ser uma organização cénica, autónoma, do texto dramático, do que a passagem desse texto ao palco, facto que, entre 1910 e 1930, conduziu à concepção clássica de encenação - como, por exemplo, a de um Jacques Copeau - e se aplica até às rupturas de Brecht e Artaud. A encenação é então concebida como "a actividade que consiste na disposição dos diferentes elementos de interpretação cénica de uma obra dramática, num certo tempo e num certo espaço de representação" (Copeau 1955: 7).

Lembremos então as principais etapas da evolução do conceito de encenação, desde a sua origem até aos nossos dias.

\section{Dupla origem da encenação - naturalista e} simbolista - com Émile Zola / André Antoine e Paul Fort / Lugné-Poe.

Para os primeiros, a cena deve reproduzir exactamente o meio social e o mundo concreto; para os segundos, ela evoca o mundo de maneira alusiva, concentrada e poética. Esta oposição diferencia, parcialmente, o teatro popular (Antoine, Firmin Gémier, Charles Dullin) do Teatro de Arte (Fort, Lugné-Poe). 
Vsevolod Meyerhold (à esquerda) nos ensaios

d'O inspector-geral, de Gogol, 1926

Konstantin Stanislavski, no final da sua carreira, no seu estúdio privado, fot. Museu do Teatro de

Arte de Moscovo. Bertolt Brecht nos ensaios

d'A vida de Galileu Berliner Ensemble, 1956

Jean Vilar em 1969, no Festival d'Avignon fot. Bruno Réquillart.
2. Reacção antinaturalista e estudo do espaço. Adolphe Appia e Edward Gordon Craig. Persuadidos da autonomia estética da cena, estes teóricos buscam os elementos essenciais da representação: 0 actor iluminado num espaço.

3. Vanguardas russas (Stanislavski, Meyerhold, Taïrov, Vakhtangov, Michael Tchekov). Interessam-se pela formação do actor, baseada na sua técnica interior e exterior.

4. Copeau e a seguir o Cartel (Georges Pitöeff, Dullin, Louis Jouvet, Gaston Baty). Marcam o apogeu da reflexão sobre a leitura dos textos e inauguram a "era cenocrática", na qual o encenador controla os signos o mais rigorosamente possível.

5. Rupturas de Artaud e Brecht. 0 autor d'O teatro e 0 seu duplo reclama uma cena autónoma, que não se interessa pela passagem do texto à representação, transformando a encenação num acontecimento único "toda a criação advém da cena" -, ideia que nos anos 60 se prolongará na arte da performance. Para o dramaturgo alemão, pelo contrário, a encenação não tem valor em si, sendo apenas o terreno de confronto entre a prática cénica e a prática textual (a leitura crítica do texto), que só ganha significado enquanto arma histórica e política.

6. Democratização e descentralização teatrais (anos 50 e 60), sob o duplo patrocínio de Jean Vilar e de JeanLouis Barrault. Para Vilar "os verdadeiros criadores dramáticos destes últimos 30 anos não são os autores, mas os encenadores" (1955: 71), o que todavia não o impede de preconizar o despojamento e a austeridade da representação; para Barrault, a cena reconcilia-se com o teatro de arte e com uma cenografia não raras vezes ornamental.

7. Ruptura de 1968 e a reacção dos anos 70 . Coincidem com a decadência da teoria, com a (proclamada) "morte do autor" (Barthes, Foucault), com a encenação como prática significante - obra aberta ou metatexto (o texto cénico impondo-se ao texto dramático). Apesar deste fechamento narcisico da encenação, os artistas norteamericanos da performance ou da música erudita (Bob Wilson, Merce Cunningham, Richard Foreman, John Cage, Philip Glass) conseguem "desencravá-la" e abri-la à performance.

8. Anos 80: da experiência socialista francesa (1981) à queda do muro de Berlim (1989). Diversificação de práticas culturais - o tout-culturel - reduz a importância do teatro de pesquisa e mesmo de toda a prática teatral.

9. Viragem de 1989. Abre-se uma nova era - de que ainda não saímos - de incertezas políticas e artísticas que, de tão numerosas, não as podemos inventariar no presente ensaio.
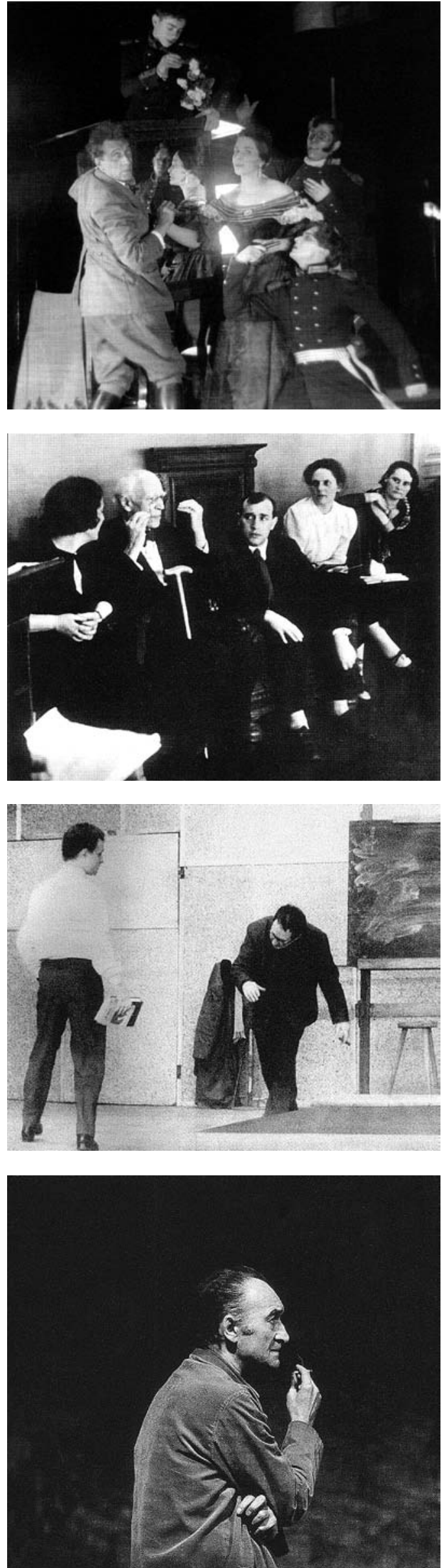

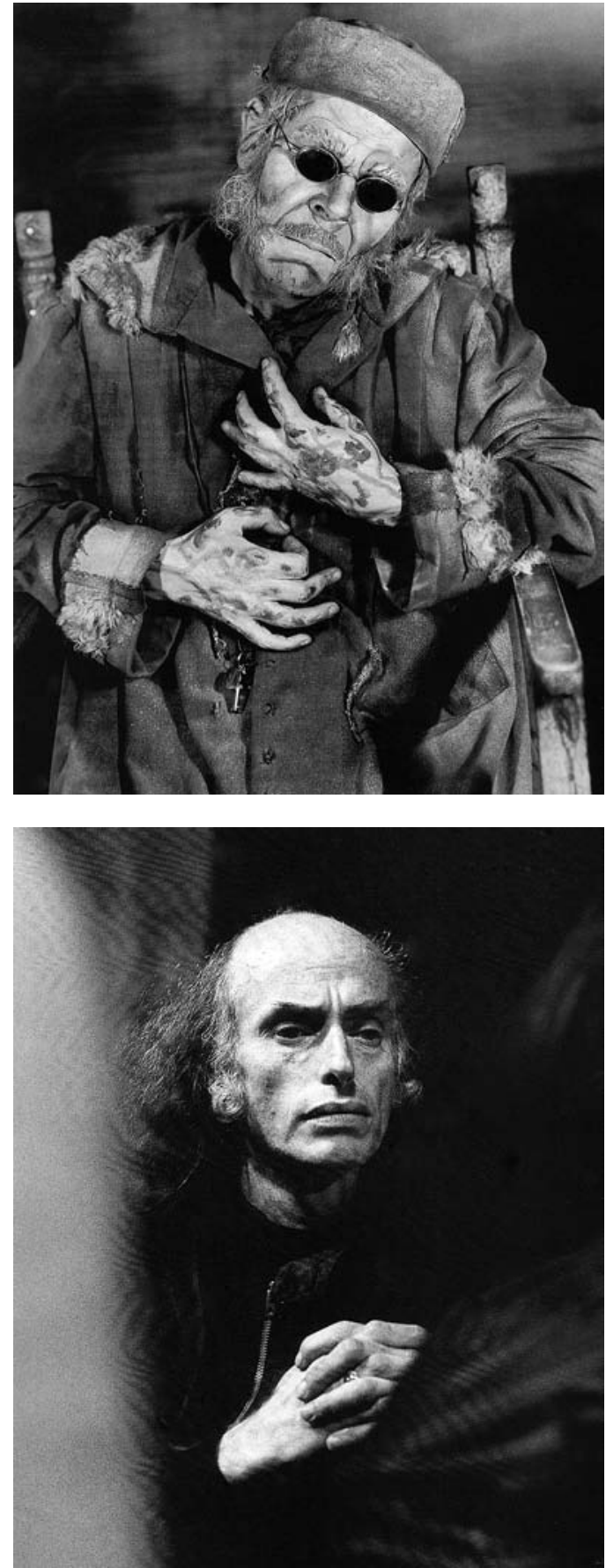

Apesar de tudo, a encenação continua a ser o melhor instrumento para avaliar a evolução do teatro. As mudanças epistemológicas da história e da teoria da encenação ajudam-nos a melhor reconstituir as tendências da arte teatral na sua longa duração.

\section{A evolução das práticas de encenação nos anos 90}

Este movimento explica-se por duas séries de factores estreitamente ligados entre si, os extrateatrais e os teatrais, mas que aqui se distinguem por pura comodidade de exposição.

1. Os factores extrateatrais. São os mais decisivos, na medida em que tocam o conjunto da vida social, à qual
Roger Blin no papel de Hamm, em Fim de festo de Samuel Beckett, 1957, fot. Thérèse Le Prat.

os artistas não se podem furtar. Os efeitos da globalização e da privatização da economia repercutem-se nas possibilidades económicas da criação (Menger 2002). Muitos grupos ou artistas independentes desaparecem por não conseguirem obter os apoios e subsidios que tornariam viáveis os seus projectos artísticos. 0 compromisso das co-produções internacionais conduz muitas vezes a uma estandardização de procedimentos estéticos e à sua sujeição a critérios sociológicos limitativos.

1.1. 0 lugar que o teatro ocupa na arte - o seu tempo artístico - evoluiu consideravelmente. Por um lado, o teatro é reconhecido pela comunidade e pela escola, apelando-se à sua capacidade para resolver ou dirimir conflitos sociais e culturais; por outro lado, ele tende para a uniformização imposta pelos criadores institucionalizados, facto que hipoteca criações alternativas.

1.2. As condições de produção pioram nitidamente com o fim do Estado Providência e o consequente desaparecimento (nos ex-paises de Leste) ou diminuição dos subsidios estatais ou de outras entidades, facto que se repercute nas condições de sobrevivência da maioria das estruturas teatrais.

1.3. Estes condicionalismos representaram para muitos artistas o fim da ilusão de que o teatro mudaria a sociedade e a vida. Dai que hoje se reconheça ao teatro, quando muito, um valor na busca individualista ou hedonista.

1.4. As expectativas do público são, por isso, diferentes: tornaram-se menos exigentes, menos políticas, mais resignadas e mesmo medíocres. Já não existe "um público" homogéneo e unânime, mas "públicos" seccionados pelos vários géneros: cada grupo interessa-se apenas por um tipo específico de espectáculo, sem abarcar o conjunto das práticas artísticas. A sociedade do entretenimento acomoda-se facilmente a esta segmentação de hobbies, tão do agrado desses minipúblicos de "aficionados".

2. Os factores teatrais. Os factores directamente ligados à criação teatral são - ainda que menos visíveis - tão importantes quanto as modificações da vida sócioeconómica.

2.1. Ao longo dos últimos dez ou quinze anos, a escrita dramática renovou-se profundamente e a encenação teve de inventar novas fórmulas de espectáculo, simultaneamente mais simples e mais sofisticadas (Pavis 2002). Todavia, estes fenómenos não são novos. Vitez chegou mesmo a estabelecer uma lei da evolução do teatro, a partir de Claudel e Tchekov, atribuindo aos "poetas dramáticos" a responsabilidade pelas grandes mudanças formais do teatro, tais são os desafios que colocam aos artistas da cena (Vitez 1991: 322-23).

2.2. Apesar de uma ausência de preocupação cenográfica ou ornamental, a multiplicação das experiências de escrita mudou a maneira de representar, não já em encenações fragmentárias, mas em minipeças centradas num actor rigorosamente dirigido. A escrita, muitas vezes enigmática, não é esclarecida pela encenação, mas torna-
Julian Beck em 1968 no Festival d'Avignon, fot. Bruno Réquillart. 
Peter Stein e Edith Cleve

nos ensaios d'A Oresteia

de Esquilo,

Schaubühne, 1980

fot. Ruth Waltz.

se legivel logo que a prática cénica encontra uma maneira coerente de operacionalizar o texto. Aprendeu-se, por exemplo, a representar Koltès ou Vinaver e todos os outros autores cuja escrita não prescreve um determinado modo de representação. É preciso dizer que o desempenho do actor não só dispõe de uma experiência substancial - de Stanislavski a Grotowski -, como de uma vasta paleta de estilos. A selecção destes estilos depende do encenador, bem como os códigos e os modos de explorar o texto dramático, qualquer que seja o tipo de texto ou a época representada.

2.3 Em contrapartida, os estudos sobre o espaço e a relação palco / sala não acusam desenvolvimentos sensiveis depois dos anos 60 e até aos anos 80, como se já se tivessem testado e esgotado todas as soluções.

Frequentemente, a encenação recupera mesmo a relação frontal de antigamente, inclusive a da velha representação à italiana.

2.4. 0 que no fundo mudou ao longo da história da encenação foi a ideia que dela se faz e as ferramentas teóricas que servem a sua concepção. Desde os inícios (1880) até ao seu apogeu clássico (c. 1950), a encenação foi antes de mais uma noção histórica e filológica, que serviu para "transferir" o sentido do texto para o palco. Quando nos anos 60 e 70 ela se assume como texto "espectacular" ou "metatexto", ou seja, um objecto semiológico, tende a fechar-se sobre si e a funcionar em circuito fechado. Só com as experiências norte-americanas da performance, nos anos 80, é que ela se abriu a outras práticas artísticas e culturais, adquirindo uma dimensão antropológica, ou mesmo culturalista, que veio a exigir os contributos das ciências sociais - nomeadamente da antropologia dos Performance Studies - para fornecer uma teoria explicativa. Neste contexto, a encenação já não se reporta a uma teoria dominante, como o estruturalismo, a semiologia, o marxismo ou a psicanálise mas, pelo contrário, preconiza um ecletismo e um cepticismo muitas vezes apelidado de "pós-moderno", "pós-estrutural" ou "pós-dramático" (Lehmann 2002).

Ainda hoje, notamos que muitos artistas manifestam uma certa resistência às teorias da encenação, tal como o fazem em relação aos programas de ensino, a qualquer reflexão pós ou acerca do socialismo ou às abordagens sociológicas. Outro tipo de teoria parece, todavia, prestes a emergir: já não a do "geneticista", que descreve passo a passo a construção do espectáculo, mas a do "pragmático", que propõe uma prática para o teatro, que pode ser imediatamente teorizada e modificada em função das observações "no terreno".

3. Razões desta evolução. Teorizar a recente encenação é tão difícil como elaborar a sua história, porque ela não pára de evoluir, o que é visivel na divisão do trabalho, na estandardização e na guetização do teatro.

3.1. A nova divisão do trabalho resulta da mudança do contexto sócio-cultural, pelo menos no que diz respeito

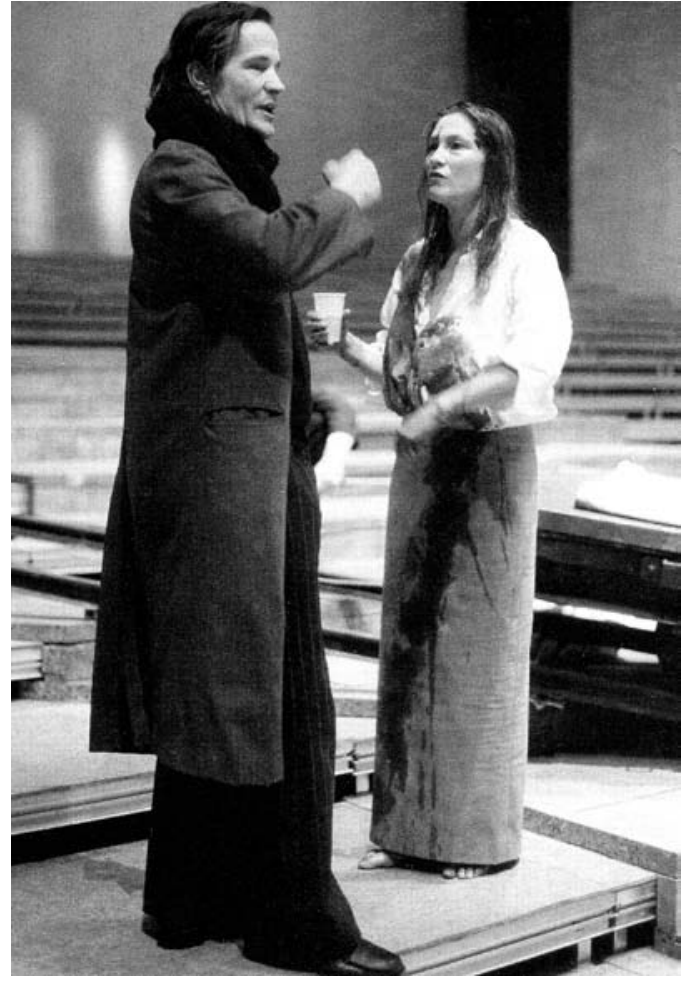

aos Centros Dramáticos e aos Teatros Nacionais. Com efeito, a criação teatral exige novas especializações, como por exemplo a do sonoplasta, a do luminotécnico (assistido por computador) e a do videasta (imagens em directo ou diferidas). Estas especializações altamente técnicas impõem-se ao encenador, que nem sempre as domina, apesar de se esperar que as integre na sua criação. Novas identidades profissionais aparecem constantemente. Contratam-se colaboradores pontuais para tarefas precisas, muitas vezes complexas, como por exemplo a iluminação, o som e a coreografia. Tal como as anotações ao texto nem sempre passam para a representação, estas intervenções atribuem à encenação uma marca própria do colaborador, uma determinada assinatura que esteja em voga. Para além disso, esta invenção de novas tarefas e funções depende dos hábitos de produção e das leis da produtividade, o que limita muito as possibilidades da experimentação.

3.2. A estandardização dos grandes modelos da encenação resulta também desta nova divisão do trabalho e provoca uma dupla limitação: por um lado, uma exigência de originalidade artística a todo o custo (exige-se sempre qualquer coisa inédita e assombrosa); por outro lado, os resultados deverão corresponder aos gostos dos "aficionados". Do "grande espectáculo" (como o de Robert Hossein e o seu "no teatro como no cinema") a um one(wo)man-show no Festival Off de Avignon, a lista de modelos é infinita e o leque de escolhas enorme. Mesmo as produções fora do circuito comercial - o teatro universitário, por exemplo - manifestam os seus lugarescomuns e os seus tiques; a vanguarda, ou o que dela resta, comove-nos, por vezes, pelas referências inevitáveis à libertação das formas e dos costumes.

Assistimos, assim, a uma marginalização ou - para sermos mais positivos - a uma autonomização das práticas cénicas, como se o teatro se tivesse partido em mil bocados e a encenação devesse solucionar todos os casos 

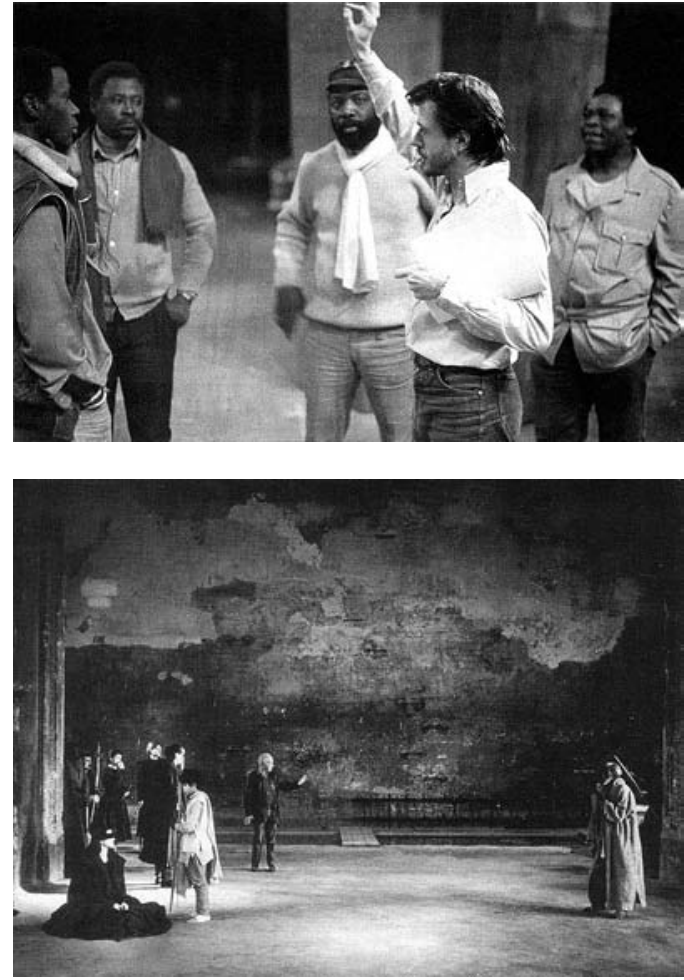

particulares, montando o puzzle dos pedaços do espelho quebrado. 0 facto é que o teatro vai perdendo a sua alma, pois deixou de ser uma arte colectiva.

A esta nova existência do teatro junta-se o seu receio face às outras artes. Diferentemente dos anos 70, nos quais, graças à abertura do Festival de Outono parisiense ao meio artístico norte-americano, se reunia alegremente artes visuais, dança, performance e teatro, os últimos vinte anos do século XX não têm cruzado, na maioria das vezes, as fronteiras interartes. Apesar deste purismo, alguns - poucos - artistas não hesitaram, nestes últimos anos, em "passar os limites". Jacques Rebotier, músico e poeta, constrói espectáculos aliando os princípios de artes diversas "apreender uma arte com os utensílios de uma outra estimula a invenção. Qualquer arte é fraccionada e remete para outras" (Rebotier 2002: 71); Valère Novarina confronta a sua pintura e a sua criação poética dentro do acontecimento cénico; François Lazaro fabrica marionetas de tamanho humano, manipuladas por comediantes que representam textos contemporâneos (Lemahieu); Alain Lecucq propõe um "teatro de papel", onde a narrativa de um romancista (Mohammed Kacimi) é adaptada às subtilezas da manipulação dos espaços, dos objectos e do corpo do actornarrador-contista. Também o teatro-dança (Maguy Marin e sobretudo Pina Bausch), as artes de rua e o circo "teatralizado" forneceram muitas outras manifestações dum teatro que se abriu à arte contemporânea.

\section{As hesitações actuais da encenação}

Apesar da especialização, da estandardização e até da guetização do teatro neste princípio de milénio, parece que a encenação hesita entre várias caminhos, recusando-se a escolher entre o antigo e o moderno. Este estado de crise, esta sensação de "não avançar nada" continua e mantémse há mais de uma dezena de anos. As hesitações são, pois, a marca de uma época de tensões e de tendências opostas.
A crise - se é que ela existe - não reside na escrita dramática que, de Vinaver a Koltès, tem sofrido uma profunda renovação nos últimos 20 anos; reside antes no teatro como instituição, que, não ousando libertar-se completamente dessa amante ruinosa que é o teatro subsidiado, só se aguenta graças aos contratados a prazo e a outros explorados crónicos. Essa crise reside fundamentalmente na derrisão estrutural da encenação, considerada um terreno problemático e ruinoso na sua relação com as obras e com o público, simultaneamente bulímico e indiferente. Em suma, a encenação é tida como responsável pela dificuldade que o teatro tem em nos afectar. Não sem malícia, é assimilada a "essa sanguessuga repugnante que impõe o seu cinzentismo a toda a França e, ainda por cima, faz sempre os mesmos espectáculos chatos" (Regnault 2002: 73). É este o tipo de enfastiamento que torna os nossos concidadãos hesitantes em passar as portas dos teatros. Por isso, é conveniente que, antes de expormos as novas funções da encenação (revisão e reconstrução), nos detenhamos um pouco sobre alguns bloqueios da encenação de hoje, pelo menos no que diz respeito à França.

\section{A qualidade da fidelidade. Durante muito tempo,} estabeleceu-se a relação do texto com a encenação em termos de fidelidade ou de traição, como se fosse possivel, nesta matéria, afirmar claramente se a cena "serve" o texto ou se ela "se serve" dele (para parafrasearmos o velho jogo de palavras de Vilar). Julgávamos que esta questão estivesse resolvida e este debate concluido desde os anos 70 - os anos da semiologia. Pensávamos ter sido então demonstrado que qualquer encenação "intervém" no texto, constituindoo, ao atribuir-Ihe sentido. Ora, hoje em dia, essa mesma discussão ressurge amiúde e alguns teóricos e críticos continuam a opor a fidelidade à obra a uma utilização livre ou pós-moderna dos textos, o respeito filológico a uma relação pós-moderna, o punk à cultura. É verdade que se tornou melindroso dar conta de todas as vertentes. Por um lado, proclama-se que, na representação, o texto se situa no mesmo plano dos sistemas não verbais, sem qualquer predomínio sobre eles; por outro, anuncia-se actualmente o regresso do assunto e do autor que, por assim dizer, novamente se tornam proprietários do texto. Esquecemonos, porém, que é necessário examinar qual o dispositivo de leitura que a encenação utiliza e quais as suas consequências para a compreensão do texto.

2. 0 fetichismo do fragmento. A encenação dos anos 70 e 80 deixou-se fascinar pelos textos não dramáticos, muitas vezes fragmentários, reunidos aleatoriamente numa vasta "colagem" (mais do que uma montagem). Este fascínio foi diminuindo por cansaço e pela vontade de voltar a formas mais orgânicas, a verdadeiras peças "neo-dramáticas", como é o caso de Yasmina Réza, Eric-Emannuel Schmitt ou JeanClaude Grumberg. Acrescente-se que o trabalho sobre o pormenor, o alarde sonoro e visual, as rupturas e os fragmentos, já não constitui um problema desde que, a

\section{Patrice Chéreau \\ nos ensaios de Combate \\ de negro e de cães, \\ de Bernard-Marie Koltès, Théâtre Nanterre- \\ Amandiers, 1983, \\ fot. Nicolas Treatt.}

Peter Brook nos ensaios de Mahabharata,

Theâtre des Bouffes du Nord, 1985, fot. Michel Dieuzaide. 
partir de Grotowski, Eugenio Barba ou Bob Wilson, os actores são capazes de reconstruir por si próprios uma organicidade.

3. A enunciação. Depois dos anos "expressivos" (décadas de 60 e 70) - mais marcados pelo grito, o fôlego e a expressão corporal - o texto, fragmentado ou orgânico, reencontra o seu valor musical, plástico, teatral e, por vezes, quase declamatório. Em resposta à prática e ao ensino de Antoine Vitez, o palco tornou-se um lugar onde a "nação" (ou pelo menos os actores) pode trabalhar, usar e enriquecer a língua na sua dimensão quase "caligráfica" e formal. 0 palco serve ainda para trabalhar a lingua num laboratório onde se testam as entoações, a acentuação e a retórica de ontem e de hoje. Stéphane Braunschweig, Christian Schiaretti, Robert Cantarella, Alain Olivier - todos eles antigos alunos de Vitez - exigem dos seus artistas uma dicção sustida, que pode parecer ligeiramente afectada, mas que sobretudo se esforça por dizer da forma mais precisa possivel a partitura vocal e física.

Este cuidado posto na dicção é também sintomático da vontade de o teatro subordinar à palavra a sua função de testemunho: "No teatro tudo começa quando o portador de uma má notícia começa a gaguejar, emocionado pela importância da sua missão. Nesse momento, transparece uma verdade muito forte na obstinação que demonstra em querer, apesar de tudo, cumprir a sua função" (Bigel 1994: 133).

4. A herança textual. 0 texto mantém-se, pois, um valor seguro e estável, mas não em virtude de uma pretendida fidelidade ao sentido ou à tradição da interpretação. E se há uma tradição, ela é a da declamação clássica francesa, a da retórica vocal e gestual. É, de resto, esta a razão pela qual a encenação francesa tem dificuldade em abrir-se a uma tradição completamente diferente, como a do teatro "performativo", "mais visual ou mais tecnológico, como o praticam Robert Lepage, Elisabeth Le Compte, Bob Wilson ou Peter Sellars" (Féral 1998: 18).

A performance ou o teatro da desconstrução, ainda que bem acolhido nos anos 70 e 80 , nunca ganhou raizes neste pais demasiado clássico. Quanto muito, ajudou a "ultrapassar", pela ironia e pela citação, as vanguardas nascidas nos anos 20 ou 30. Este interlúdio pós-moderno serviu-se das vanguardas históricas, mas para Ihes criticar o radicalismo, a originalidade, a autenticidade e a inovação. Assim, deu azo a poucas produções "desconstrutivistas", já que o "desconstrutivismo" de um Derrida ou de um Lyotard não regressou da sua digressão pelos Estados Unidos, para criar uma estética ou um movimento francês (ou europeu). Nota-se já, aliás, nos encenadores mais propensos à "desmontagem" pós-moderna um cansaço diante da desconstrução. Com efeito, a influência da estética pósmoderna já não se faz sentir senão na mistura de géneros e estilos, na musealização das práticas espectaculares. E mesmo o espectador actual sucumbe à conservação museológica de todos os espectáculos que viu, guardando- os na memória, classificando-os, organizando-os em colecções particulares, embora sem saber exactamente a finalidade desta conservação.

5. 0 impasse do teatro intercultural. 0 regresso do texto e o cuidado posto em proferi-lo explicam, sem dúvida, o relativo desinteresse pelo teatro intercultural, considerado por alguns demasiado naïfe, simultaneamente, apostrofado por puristas e fundamentalistas. É certo que o teatro permanece como um dos últimos lugares onde os artistas recorrem livremente a fontes diversas, sem se preocuparem, pelo menos por agora, com o "politicamente correcto". No entanto, o moralismo e o fundamentalismo também aí espreitam os artistas mais independentes, do mesmo modo que os teóricos pós-modernos rejeitaram as identidades étnicas ou religiosas. Nos anos 80, o Mahabharata de Peter Brook procurava uma essência humana acima dos particularismos étnicos, esforço que the valeu um bom número de críticas, quer dos fundamentalistas, quer dos intelectuais de boa (e correcta) consciência. Por exemplo, até à sua última criação (Le dernier caravansérail, de 2003) Mnouchkine não se interessou pela imitação de formas teatrais asiáticas, mas pela questão étnica traduzida nas relações de força sócio-económicas e políticas (L'Indiade, Sihanouk).

6. A desconfiança em relação aos mestres. Perplexidade similar caracteriza os encenadores da "jovem geração" (de 30 a 40 anos) em relação aos seus predecessores. Há muito tempo (vinte anos?) que os grandes pensadores - Barthes, Lévi-Strauss, Foucault, Lacan ou Althusser, entre outros já não são sistematicamente consultados na análise dramatúrgica ou na encenação. Do mesmo modo, as referências obrigatórias ao "santo" Artaud ou ao "camarada" Brecht tornam-se raras e mais irónicas do que deferentes. Já não existe nenhum laboratório de pesquisa que se esforce para isolar um sistema de representação ou uma encenação aplicável a qualquer tipo de texto ou produção: nem Vilar, nem Planchon, nem mesmo Vitez. As últimas grandes figuras emblemáticas da cena - Kantor, Grotowski, Strehler, Blin - desapareceram e não foram substituídas. Os sobreviventes são-Ihes indiferentes: Planchon é pouco imitado e ninguém, entre os jovens talentos, ousa ir tão longe na "lentidão" como fora Claude Régy (n. 1923), a nossa "excepção cultural" e o nosso bisavô lutador.

Efectivamente, a nova geração de "quarentões" do teatro prefere os avós aos pais, rejeitando os mestres recentes (Patrice Chéreau, Jean-Pierre Vincent, Georges Lavaudant, Alain Françon), deixando-se fascinar pelos antigos (Copeau, Jouvet, Vilar e... Régy). Embora oriundos da instituição e, ainda jovens, colocados à frente de Centros Dramáticos Nacionais, figuras como Stanislas Nordey, Christian Schiaretti, Demarcy-Mota, Éric Vignier ou Olivier Py desconfiam do modo de produção dos teatros subsidiados e dos seus brilhantes antecessores, embora hesitem em rejeitá-los por aspirarem a suceder-lhes. 


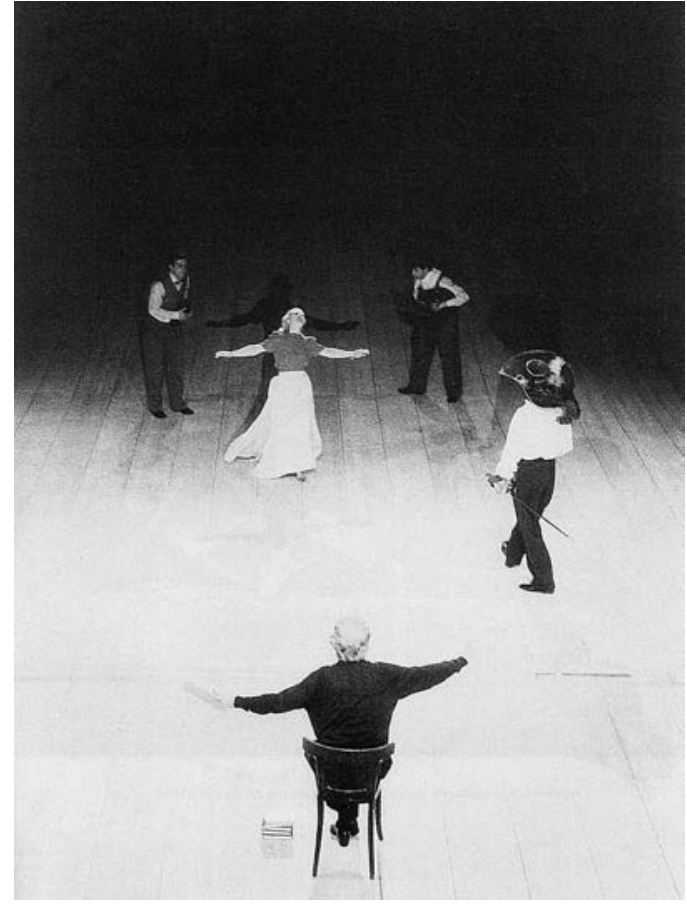

7. Os novos espaços. Existem poucos espaços alternativos, devidamente reabilitados para as necessidades da causa teatral, e as escassas tentativas, infelizmente pouco convincentes por causa do amadorismo de alguns dos seus elementos, ficam isoladas tal como as performances sitespecific.

8. A política cultural. Quer se abra a novas correntes, quer continue ligada à tradição, a criação vê a sua própria existência cada vez mais submetida às leis do mercado pois, dependendo de subsídios para viver, o teatro subordina-se também à flutuação do mercado e das condições

económicas. A institucionalização do teatro, a que os artistas já não podem escapar, formou uma bolsa onde os actores são cotados, vendo quantificado o seu valor comercial. Esse processo gera projecções das perspectivas de carreira dos artistas, dedicando-se os caça-talentos a uma "espionagem industrial" para descobrir jovens talentosos, quando o seu poder de fogo e de sedução os atinge em cheio - é a crise aguda da "malta jovem"!

Tudo o que foi exposto leva a crer que, actualmente, a encenação hesita entre renovar-se ou simplesmente evoluir. Parece que os encenadores "institucionalizados" não conseguiram passar o testemunho à geração seguinte, a qual, de resto, se afasta dos pais para se refugiar nos egrégios avós. Se a encenação hesita tanto em encontrar o seu caminho é precisamente porque tem muito a rever e a preparar para, então, edificar o teatro dos seus sonhos.

\section{Novas funções da encenação: rever e preparar}

Passado este momento de hesitação, a encenação não pára hoje de se questionar sobre o que deve rever nesta paisagem sombria ou sobre o que deve preparar para um futuro que não se anuncia muito cor-de-rosa.

1. Rever a boa comunicação. 0 teatro duvida da pretensão de tudo comunicar, da tirania da informação. A encenação

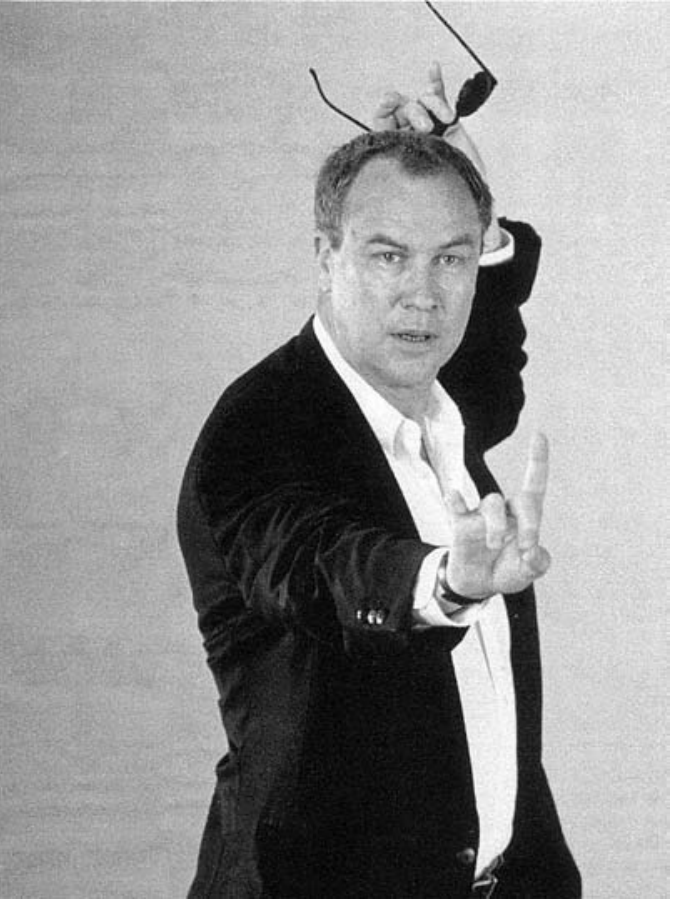

Bob Wilson, fot. Ruth Waltz

Giorgio Strehler (de costas) nos ensaios d'Elvira ou a paixão teatral, sete lições de Louis Jouvet, 1987 / 88, fot. Luigi Ciminaghi.

não tem - ou já não tem - de ser clara, legivel, explícita, não tem de servir de mediador entre emissor e receptor, autor e público, nem de "limar as arestas". Ela mantémse voluntariamente densa e em vez de supostamente simplificar e explicar, reintroduz a opacidade e a poeticidade dos signos, pervertendo a relação entre significante e significado. Mesmo depois dos esclarecimentos de Brecht, a encenação reivindica uma certa ambiguidade, como acontece nas encenações de Jacques Delcuvellerie (A mãe), Benno Besson (Circulo de giz caucasiano) e na mais recente de Alain Olivier ( $A$ excepção e a regra). Estes espectáculos tentavam não reduzir as peças a palavras de ordem, visando antes reintroduzir na interpretação e na cena uma dimensão poética, isto é, uma materialidade cénica intraduzivel em significados univocos.

2. Rever os textos / destruir as peças. Quando a estrutura das peças, outrora fechada, coerente, narrativa, ficcionável, se rompe e se abre, tornando-se naquilo que desde os anos 70 apelidamos de "texto", verifica-se ser dificil lêlo e representá-lo de uma única maneira, confirmando a sugestão avançada por Anne Ubersfeld de que a encenação tem precisamente por missão encontrar um equilibrio entre a abertura do texto (a sua ambiguidade) e a tendência natural para explicar, justificar, interpretar as lacunas da obra. Inversamente, quando a obra é uma peça coerente, com estruturas previsíveis, linguagem dramática clássica e uma intriga muito explícita, a encenação consistirá em reintroduzir "texto", isto é, "jogar" com as estruturas de ambiguidade semântica. Quando assim acontece, ela complexifica-se, adensando o prazer do enigma.

3. Colmatar a ausência de referências culturais. Reside aqui uma das principais funções da interpretação de textos dramáticos, nomeadamente quando a obra pertence a uma área cultural diferente da do público. Trata-se, pois, de fornecer de forma discreta as referências em falta, as chaves de leitura indispensáveis. Esta "ajuda" ao espectador é-Ihe concedida sem que ele esteja consciente disso e, por 
vezes até, contra sua vontade. Dito de outro modo, o espectador é conscientemente manipulado (a encenação é sempre uma activação ideológica inconsciente).

4. Rever a fábula. Quando as peças se transformam em textos abertos, sem intriga clara, ou quando os encenadores "nos seus espectáculos, nunca dão a impressão de tratar a história por aquilo que ela é" (Tackels 1994: 90), a encenação deve preenchê-las ou pelo menos substituir-Ihes a estrutura organizadora. Do mesmo modo, a encenação tem dificuldade em substituir a intriga por jogos de representação ou tiques de boulevard, não conseguindo assim preencher o vazio e justificar a recusa de uma leitura que se apoia em estruturas dramáticas espácio-temporais e na história.

\section{As obrigações actuais e futuras do encenador: instruir e construir}

Se a encenação é concebida como uma performance que integra actividades vivas e instáveis - mais improvisadas do que codificadas -, então esperar-se-á que o trabalho do encenador se diversifique e enriqueça. A encenação deverá assim resolver a sua contradição constitutiva: pois, por um lado, nasceu (e continua a alimentar-se) de uma divisão do trabalho, o que ocasiona a integração continuada de novos colaboradores e, por outro lado, só tem sentido se consegue apreender globalmente o espírito da representação, segundo uma coerência harmónica conferida pelo encenador, que assim se torna o autor cénico que controla todos os fios do espectáculo. Julgamos ser este o aspecto que mais preocupa o encenador, pois ele é obrigado a desdobrar-se e multiplicar-se, sem deixar de ser ele próprio. E na medida em que os seus colaboradores adquirem novas valências, o papel do encenador é realmente difícil, tanto mais que não deixa de se (re)definir.

1. 0 actor. Embora sejam imagináveis todas as formas de representação, a maior parte dos encenadores exige que 0 actor seja eminentemente orgânico. Significa isto que ele tem de fazer parte do que diz, da maneira como diz e do conjunto da representação. Tal como sugere a actrizencenadora Pol Pelletier, se este actor orgânico existisse, tornar-se-ia o seu próprio encenador: "Creio que, num dado momento, os encenadores não serão necessários, porque se os actores forem completamente livres, necessariamente farão coisas mais belas, mais exactas e organicamente mais originais, pois só farão o que o seu ser único pode fazer" (Pelletier apud Féral 1998: 251).

2. 0 autor. A relação entre encenador e autor já não sofre da suspeita de o primeiro explorar o segundo. $\dot{E}$ preferencialmente o autor que necessita do encenador, e ainda mais do actor, para testar e abrir os sentidos possiveis do texto. Esta relação traz vantagens para as duas partes. Assim, o autor - para evitar traições ou para expressar um ponto de vista -, já não se sente mais obrigado a realizar sozinho a sua peça (caso em que correria o risco de ficar prisioneiro do seu próprio texto). Pode, portanto, confiála a um actor com condições para a representar, assim como para a revelar da melhor forma possivel ao próprio autor e ao espectador.

3. 0 dramaturgista. No sentido alemão de "conselheiro literário", o dramaturgista já quase não é utilizado pelo encenador e tem tendência a desaparecer. A sua função permanece, todavia, útil, embora seja assegurada em grande parte pela encenação. Com efeito, depois dos anos 60 e 70, o labor do dramaturgista tornou-se uma prática inoportuna que, ocultando as nervuras textuais sob referências culturais e análises políticas, impedia uma relação directa com o texto, distanciando os actores da representação. Depois da vaga brechtiana, a instituição francesa abandonou a figura do dramaturgista. Desde Vitez que o encenador integrou essa função no seio da encenação, optando por iniciar o trabalho no palco com os actores e excluindo um estudo prévio que decidisse as futuras escolhas cénicas. Entretanto, é muitas vezes a análise dramatúrgica que faz falta, sobretudo no que diz respeito à análise ideológica e histórica de uma peça, capaz de actualizar e adequar a sua pertinência. Se bem que a encenação deva evitar o pesado didactismo brechtiano, ela deve reinventar e integrar esta função dramatúrgica.

4. 0 director de actores. A procura de uma nova escrita e duma análise integrada da interpretação leva o encenador a concentrar-se prioritariamente na representação e na direcção de actores, pondo de lado os aspectos materiais da cenografia, do som e da iluminação. Muitas vezes, esta redução da encenação à direcção de actores é imposta por um modo de produção muito pobre. Fazendo da necessidade virtude, o director de actores interessa-se somente pela representação, seguindo a simples ideia de que o actor tem de ser "parido" por ele e até (talvez) provocado, maltratado e mesmo enganado. Pior ainda, quando se distinguem direcção de actores e encenação, esta reduz-se ao supérfluo, à invenção de um espaço, duma cenografia, dos figurinos, etc. Acontece mesmo que a crítica dissocia muitas vezes as duas funções, a direcção e a encenação.

0 lugar particular hoje concedido à direcção de actores não deverá eliminar a função da encenação. A direcção tem efectivamente um papel fundamental, mas não elimina a função mais global da encenação, fazendo, pelo contrário, parte dela. Com efeito, esta função alimenta e ilumina a encenação. 0 desempenho dos actores, por mais subtil e despercebido que seja, só ganha sentido na totalidade da realização cénica. Não deixa de ser verdade que esta promoção do director de actores convém especialmente à difícil situação económica do teatro de hoje e ao desaparecimento dos encenadores "cenocratas" que produziam e controlavam tudo. 

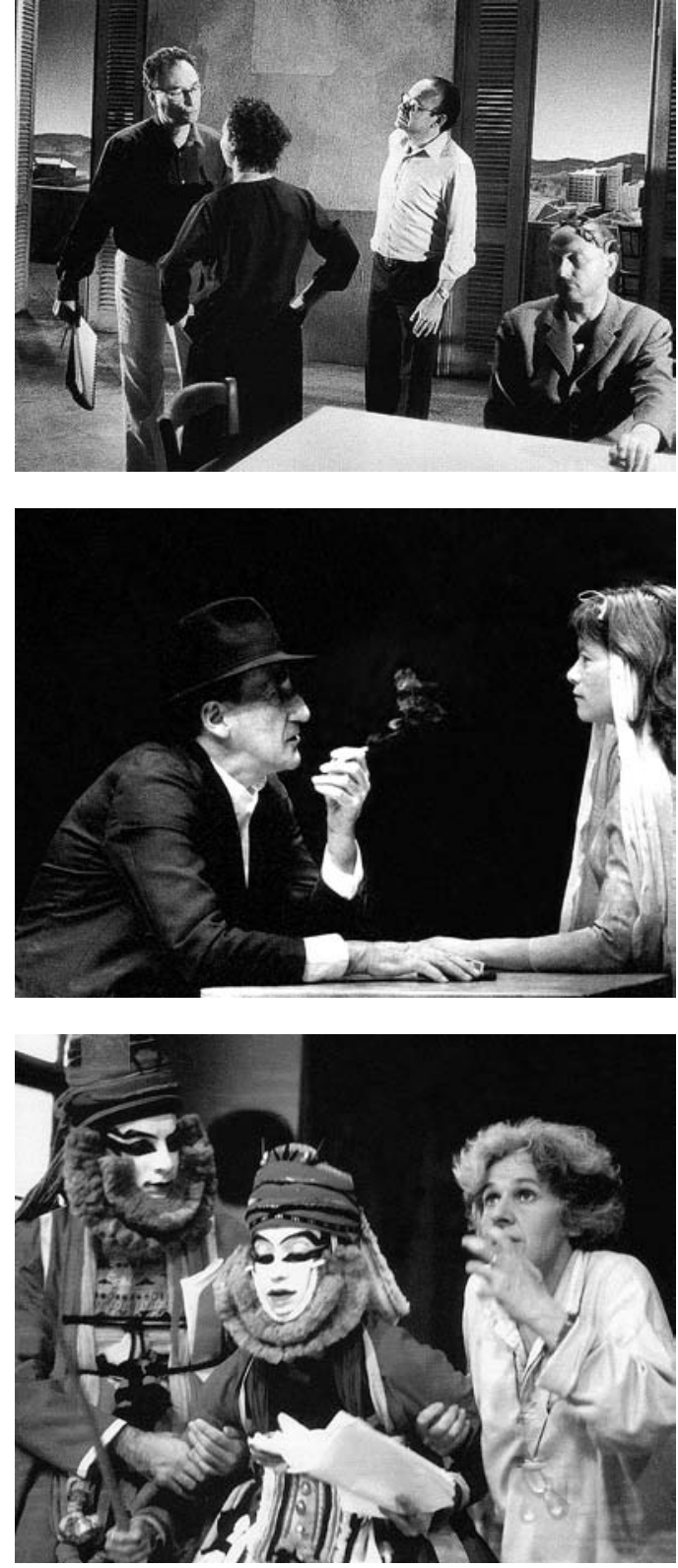

5. 0 esteta, o formalista, o coreógrafo. Em vez de a encenação deslizar para o mero casting e para a gestão burocrática, mais valia reencontrar a sua função estética de outros tempos, sem no entanto negar a sua responsabilidade dramatúrgica, ideológica e política. No fundo, é o que se pode observar em numerosos encenadores, sobretudo naqueles que apelam para o Teatro de Arte e para a herança de Vitez. A encenação reforça o carácter estético da representação: a literalidade, a teatralidade, o respeito pelas convenções e formas. Ela procurará que os actores desenhem belas e transparentes figuras coreográficas, com movimentos trabalhados, com linguagem estilizada e formal (Jean-Marie Villégier, Daniel Mesguich, Robert Cantarella).

\section{Vl. Conclusão}

Se a encenação vem directamente do princípio dos tempos, mesmo que com intermitências várias (em 1820, 1880, 1950, 1989), é muito difícil prever para onde ela vai e se conservará parte da sua identidade. Jogando com as

\section{Antoine Vitez (à esquerda) na gravação d'Electra de Sófocles, realização de Hugo Santiago, 1987, fot. Claude Bricage.}

palavras, poder-se-iam esboçar as identidades do encenador no século XX: distanciou-se do "mestre de cena" (Craig, Copeau) ao ponto de não ser mais do que um "medidor de cena", um habilidoso, um necessitado com inspiração que produz representações cénicas a metro, empurrando os peões no tabuleiro segundo as regras do jogo mas sem inspiração, tendo perdido, portanto, a noção do equilibrio. Este medidor é um agrimensor do infinito que deixou atrás de si muitas outras tarefas: a do "chefe de cena" (para a agit-prop), a do "enganador de cena" (com os Strasbergiens), do "apresentador" (nas peças pedagógicas) e ainda a de todos os "emissores de cena", os que emitem a sua mensagem do alto da tribuna com o único fim de serem bem recebidos. Contudo, este "medidor" encontra por vezes o espectador, causando nele um efeito de "sismo silencioso", visto que alguns espectáculos são como uma bomba relógio: explodem quando já foram esquecidos.

A palavra e a noção de encenação foram inventadas para uma prática teatral baseada no texto, mais precisamente no texto literário, pré-existente à representação. Será a encenação uma noção ainda legitima para um teatro que trabalha com algo que é diferente de um texto encenado, apresentando especialmente imagens sem texto, isto é, com "grandes espaços de silêncio e portanto com imagens virtuais?" (Cormann apud Corvin 1994: 126). Não será necessário encontrar uma outra palavra (e uma outra teoria) para uma encenação que trabalha com o silêncio e com signos não verbais por ela organizados?

Por certo que a teoria e a história da encenação se tornam mais precisas se for estabelecida uma tipologia que siga a cronologia e que descreva uma sequência de estéticas, ancoradas na história do teatro: encenação naturalista, simbolista, futurista, brechtiana, etc. Todavia, esta cronologia não é linear e as formas de encenação nunca são puras. Por outro lado, assim que o texto dramático deixa de ser anterior e não tem de se projectar na cena e assim que, por volta de 1950-1960, com a chegada simultânea de um teatro do corpo, da imagem e do estruturalismo, o texto é, por assim dizer, trespassado pela representação, pela cena e pelo silêncio, esse texto perde qualquer possibilidade de controlo sobre 0 acto teatral: o teatro torna-se, então, num acontecimento cénico e não já numa amostragem do sentido do texto.

Para quê, pois, substituir a noção de encenação e sobretudo de que maneira conceber e analisar o que a substituirá? Já propusemos a noção de performance, que sugere bem a acção de todos os actores empenhados no acontecimento cénico. Não é por acaso que a performance - no sentido da intervenção de um actor plástico que realiza uma acção excedendo a ideia de representação teatral - veio lançar, nos anos 60 e 70, um verdadeiro desafio à encenação e à literatura dramática. Numerosos artistas deram então ao "teatro sem fôlego" um novo vigor e uma nova presença do visivel. É neste "teatro de
Tadeusz Kantor e

Marie Vayssière em Não voltarei nunca mais, 1988,

fot. Brigitte Enguerand.

Ariane Mnouchkine nos ensaios d'Os Átridas, a partir de Euripides e Ésquilo, Théâtre du Soleil, 1990, fot. Sophie Moscoso. 


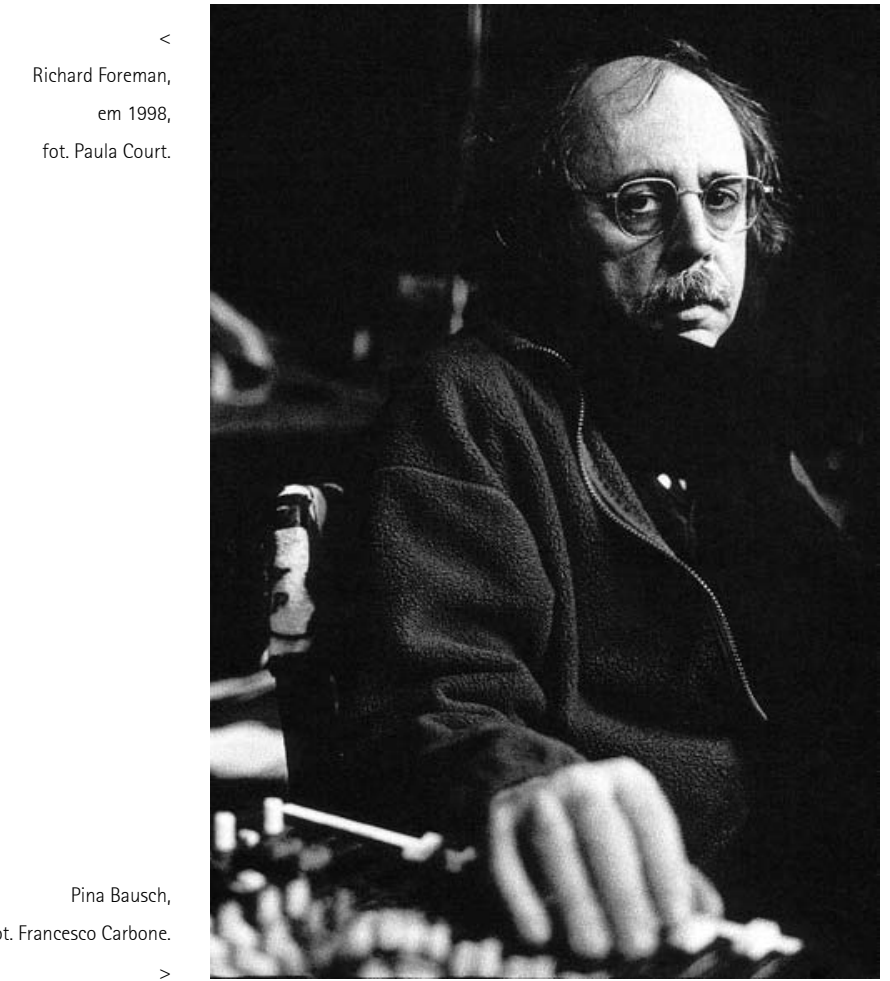

artista" que Giovanni Lista vê o futuro da representação: "No teatro, a presença do visivel e da criação plástica impõe-se a partir do silêncio do texto, tal como a totalidade dos géneros se impõe na arte a partir da morte do quadro. É por isso que o 'teatro de artista' é hoje a forma mais actual de teatro e sem dúvida da própria arte. Ele encarna talvez a única hipótese de uma renovação para o futuro" (1997: 455).

A maior parte dos historiadores e críticos juntar-seia à opinião de Lista e acrescentaria a influência da dança à intervenção das artes plásticas no teatro. No teatro dos anos 90, Michel Corvin constata assim a presença da dança e do jogo rítmico: "0 teatro desagrega-se ou melhor metamorfoseia-se: torna-se dança (...). Dança não significa coreografia, mas um tempo específico que, já não dependendo da necessidade da troca e da réplica, incute representação nos seres, isto é, uma pulsação rítmica por intermédio da qual o encenador-autor (...) faz respirar o seu texto" (1994: 125-126). Tornando-se dança e jogo rítmico, a encenação de hoje - de Wilson e Kantor ao jovem teatro - dispensa de certo modo o significado demasiado perceptivel para se consagrar a imagens mudas e silenciosas (significante puro), que se furtam, na maioria dos casos, à interpretação e aos signos.

Esta visão da encenação como dança conduz-nos uma vez mais ao silêncio e ao espectador. A encenação torna-se - ou tê-lo-á sido desde sempre? - a arte de fazer emergir o não dito, o indizivel, o silêncio. Ao passar do textual ao visual, ela não é - ou já não é? - a arte de exprimir alguma coisa, de compreender a mensagem e 0 ruído, tornando-se preferencialmente na arte de fazer emergir o silêncio para um espectador à espera de sentido. A encenação é a visualização do silêncio.

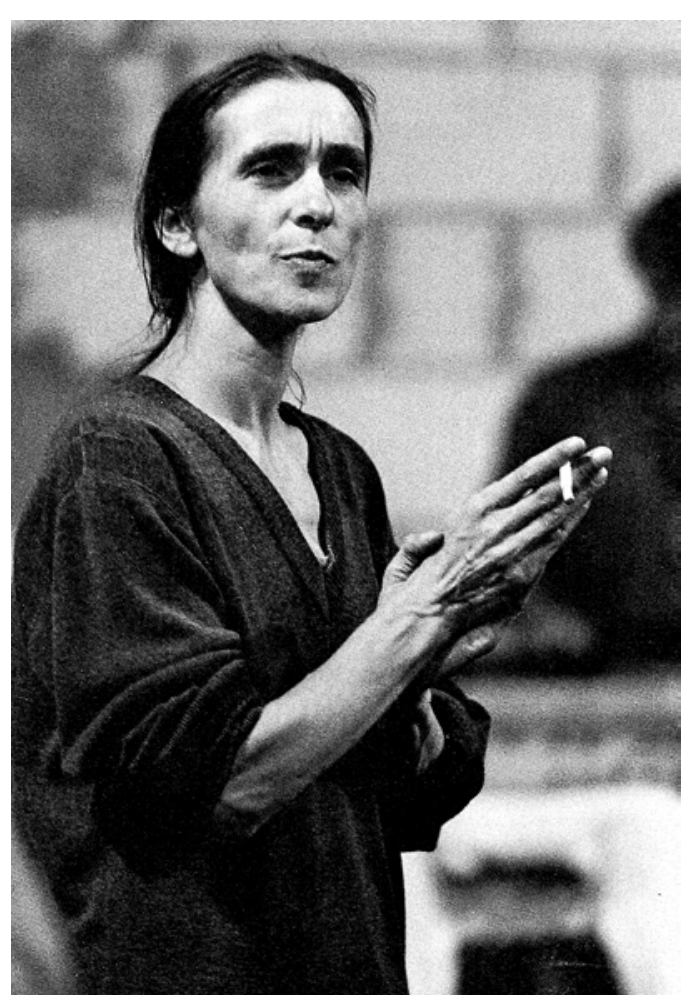

\section{Referências bibliográficas}

BIGEL, Patrick (1994), "Le messager qui bégaie", Revue d'esthétique, n. 26 , juillet 1994: Jeune théâtre, pp. 133-34.

BRAUNSCHWEIG, Stéphane (1994), "Pour un théâtre poétique", Revue d'esthétique, n. 26 , juillet 1994: Jeune théâtre, pp. 61-64.

COPEAU, Jacques (1955), Notes sur le métier de comédien, Michel Brient. CORVIN, Michel (1994), "Mise en scène et silence", Revue d'esthétique, n.

26, juillet 1994: Jeune théâtre, pp. 123-28.

DORT, Bernard (1971), Théâtre réel, Paris, Seuil.

FÉRAL, Josette, (1998), Mise en scène et jeu de l'acteur, entretiens, Tome

2: Le corps en scène, Canada / Belgique, Éditions Jeu / Lansman.

LEHMANN, Hans-Thies (2002), Le théâtre postdramatique, Paris, L'Arche.

LISTA, Giovanni (1997), La scène moderne: Encyclopédie mondiale des arts du spectacle dans la seconde moitié $d u X X X^{\complement}$ siècle, Paris, Éditions Carré | Arles, Actes Sud.

MENGER, Pierre-Michel (2002), Du labeur à l'œuvre: Portrait de l'artiste en travailleur, Paris, Seuil.

PAVIS, Patrice (2002), Analyse des textes du théâtre contemporain, Paris, Nathan.

REBOTIER, Jacques (2002), Réponse à la question précédente, Besançon, Les Solitaires Intempestifs.

REGNAULT, François (2002), Théâtre - Solstices: Écrits sur le théâtre - 2, Arles, Actes Sud.

TACKELS, Bruno (1994), "Les ombres blanches du théâtre", Revue d'esthétique, n. 26, juillet 1994: Jeune théâtre, pp. 205-10.

VILAR, Jean (1955), De la tradition théâtrale, Paris, L'Arche.

VITEZ, Antoine (1991), Le théâtre des idées, Anthologie proposée par Danièle Sallenave et Georges Banu, Paris, Gallimard.

* Este artigo é uma versão consideravelmente abreviada da conferência proferida no dia 27 de Março de 2003, Dia Mundial do Teatro, no Teatro Nacional D. Maria II, a convite do Centro de Estudos de Teatro e do então Director daquele Teatro, João Grosso. 